\title{
Digital Resources and Digital Competence: A Cross-Sectional Survey of University Students of the Childhood Education Degree of the University of Jaén
}

\author{
María del Carmen Martínez-Serrano ${ }^{1}$, María Teresa Ocaña-Moral ${ }^{2, *(D)}$ and Eufrasio Pérez-Navío ${ }^{1}$ (D) \\ 1 Department of Pedagogy, Faculty of Humanities and Education Sciences, Campus Las Lagunillas, University \\ of Jaén, 23071 Jaén, Spain; mcmartin@ujaen.es (M.d.C.M.-S.); epnavio@ujaen.es (E.P.-N.) \\ 2 Department of Didactic of Sciences, Faculty of Humanities and Education Sciences, Campus Las Lagunillas, \\ University of Jaén, 23071 Jaén, Spain \\ * Correspondence: mocana@ujaen.es; Tel.: +0034-953211974
}

Citation: Martínez-Serrano, M.d.C.; Ocaña-Moral, M.T.; Pérez-Navío, E. Digital Resources and Digital Competence: A Cross-Sectional Survey of University Students of the Childhood Education Degree of the University of Jaén. Educ. Sci. 2021, 11, 452. https://doi.org/10.3390/ educsci11080452

Academic Editors: Inmaculada García Martinez, Samuel P. León and Eleanor Dommett

Received: 20 July 2021

Accepted: 19 August 2021

Published: 23 August 2021

Publisher's Note: MDPI stays neutral with regard to jurisdictional claims in published maps and institutional affiliations.

Copyright: (c) 2021 by the authors. Licensee MDPI, Basel, Switzerland. This article is an open access article distributed under the terms and conditions of the Creative Commons Attribution (CC BY) license (https:/ / creativecommons.org/licenses/by/ $4.0 /)$.

\begin{abstract}
This work is part of a broader investigation whose main objective is to determine the domain and preferences of the students of the Childhood Education Degree of the University of Jaén regarding digital competence. The research was focused on the "use of digital resources" dimension and was developed under a quantitative and descriptive methodology, of basic type and non-experimental cross-sectional design. We worked with a sample of 135 students from the four courses of the Childhood Education Degree of the University of Jaén, who answered a developed questionnaire voluntarily and anonymously. Data collection was carried out using a virtual questionnaire on the Google Form platform. In addition, the measurement instrument was considered valid and reliable, having obtained a Cronbach's alpha coefficient $(\alpha)$ of 0.925 and a Kaiser-Meyer-Olkin sampling adequacy index (KMO) of 7.741. The results show that there are no significant differences based on the independent variables studied among most of the analyzed items. The use of ICT is beneficial for students' participation in research.
\end{abstract}

Keywords: digital competence; teacher professional development; childhood education degree

\section{Introduction}

Adaptation to the EHEA in Spain - based on the new design and structure of university degrees-has been linked to the discourse of "competencies". However, the key to the higher education reform is not based on accommodating study plans to the new structure but on a change of orientation or mentality [1]. Along these lines, [2] (p. 331) indicated that "no general shift from a teaching to a learning paradigm in higher education is possible without a parallel change in the conceptions that college and university teachers have about teaching and learning". Therefore, future teachers must be trained in competencies so that, in the future, they will be able to train their own students through competencies.

Thus, at the university level, since the Bologna Declaration (1999), the development of degree curricula has been based on a competencies approach. In the proposals for their development, it was determined that the context, needs and interests of the recipients (the students) would be considered, without forgetting the changing nature of the labor system for which they are being trained. As indicated in [3] (p. 4), which establishes the organization of official university education, "the study plans leading to obtain a degree must, therefore, have to main aim in the acquisition of competencies by students, increasing, without excluding, the traditional approach based on content and teaching hours. Emphasis should be placed on the learning methods of these competencies, as well as on the procedures for evaluating their acquisition".

Therefore, education and competency-based curricula have a direct implication in the planning of teaching-learning processes, which implies changes in the organizational 
structures and models of university institutions in general and in the teaching staff, methodologies and resources in particular [4].

From this perspective, educational objectives planned for the degree must have a clear professional orientation. In practice, two types of educational objectives defined in terms of competencies can be distinguished:

- General (cross-curricular) competencies, divided into instrumental, personal and systemic. They are understood as capacities and skills that can be used in many situations, not only in those related to the specific area of study, and thus they are transferable and common to any degree.

- Specific competencies, linked to the study areas (theoretical, practical and/or experimental knowledge and specific skills of the area) that refer to the appropriate and pertinent methods and techniques of each area [1].

Table 1 shows the generic, or cross-curricular, competencies defined in White Book of the Teaching Degree (Vol 1) [5].

Table 1. Cross-curricular (generic) competencies.

\begin{tabular}{c} 
Cross-Curricular Competencies \\
INSTRUMENTAL \\
\hline Capacity for analysis and synthesis \\
Organizational and planning skills \\
Oral and written communication in the mother tongue \\
Knowledge of a foreign language \\
Ability to manage information \\
Computer knowledge related to the field of study \\
Problem resolution \\
Decision making \\
PERSONAL \\
Teamwork \\
Work in an interdisciplinary team \\
Work in an international context \\
Skills in interpersonal relationships \\
Recognition of diversity and multiculturalism \\
Critical thinking \\
Ethical commitment \\
SYSTEMIC \\
Autonomous learning \\
Adaptation to new situations \\
Creativity \\
Leadership \\
Sensitivity towards environmental issues \\
Motivation for quality \\
\hline Volume 1. p. 84. \\
\hline
\end{tabular}

As can be seen, among the instrumental competencies, appears "computer knowledge related to the field of study". This "digital competence" is the field of study of this research since we consider that teaching has evolved from solely analog content to the coexistence of analog and digital content. Therefore, as shown in Figure 1, education in digital skills is essential for future teachers, given the knowledge they need to teach in today's society. 


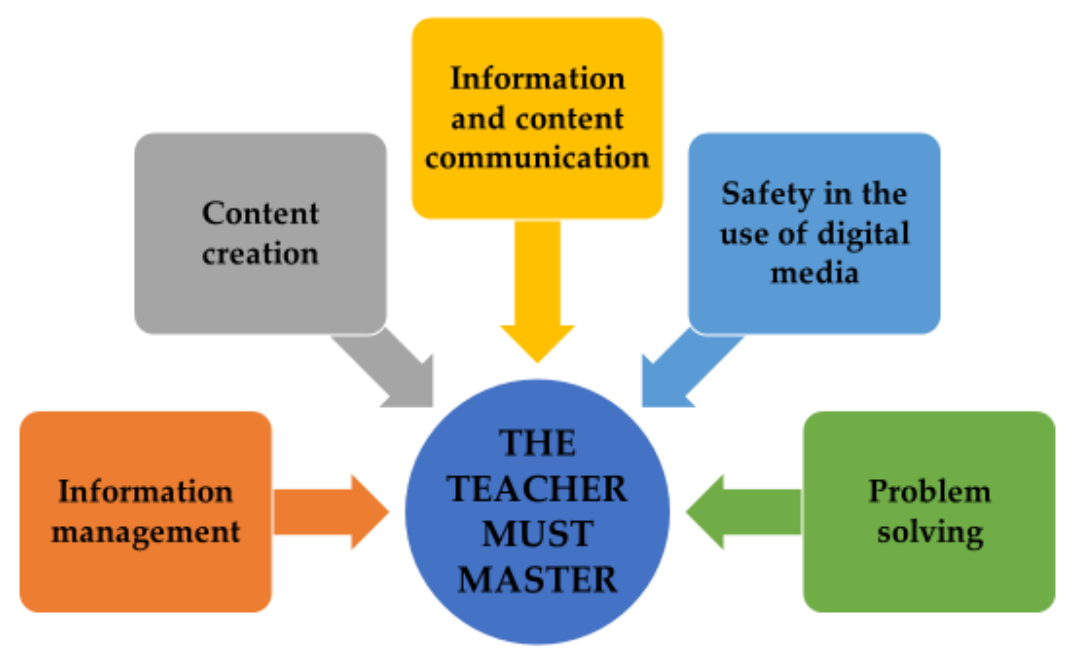

Figure 1. Digital skills for future teachers.

\section{Theoretical Framework}

Information and communication technologies (ICT) have been commonly considered as a resource that can facilitate and support the teaching-learning process. However, in the current situation generated by the pandemic (COVID-19), they are an essential resource for both teachers and students of all countries and educational levels.

The study of digital competence is recent neither for citizens nor for teachers. As indicated above, already in 2004, different "white books" were developed in Spain by a network of Spanish universities, supported by ANECA (Agencia Nacional de Evaluación de la Calidad y Acreditación is the National Quality Assessment and Accreditation Agency of Spain. It is an Autonomous Body attached to the Ministry of Science, Innovation and Universities of Spain, whose objective is to contribute to the improvement of the quality of the higher education system through the evaluation, certification and accreditation of teaching, teachers and institutions (http:/ / www.aneca.es/ANECA)), with the explicit aim of carrying out studies and case studies useful in the design of degrees adapted to the European Higher Education Area (EHEA) [6].

The model of key competencies of the 21st-century citizen [7] includes: communication in the mother tongue; competence in mathematics, science and technology; digital competence; learning-to-learn competencies; social and civic competence; entrepreneurship; and expression and cultural awareness competence.

In this model, digital competence is defined as "safe and critical use of Information Society Technologies (IST) for work, leisure and communication" [7] (p. 15).

Thus, various authors and institutions have developed different models for digital competence [8-12], which can be synthesized in the definition provided by [13], in which digital competence is understood as: "values, beliefs, knowledge, skills and attitudes to use properly technologies, including both computers and the different programs and the internet, which allow and enable the search, access, organization and use of information in order to build knowledge" (p. 54).

The DigComp (a framework for developing and understanding digital competence in Europe) study was one of the first to be carried out (2013), and its main objective was to contribute to the improvement of the understanding and development of digital competence [14]. For that, the study proposed creating a European consensus on the subject of digital competence to facilitate the development of a common framework that could help to establish clear criteria on this topic. In the case of teachers, several organizations have worked on digital competence for teachers, with the European Framework for the Digital Competence of Educators (DigCompEdu) (published in 2017 by the Joint Research Centre (JRC), which is the European Commission's science and knowledge service that employs scientists to carry out research in order to provide independent scientific advice and support to EU policy (https:/ / ec.europa.eu/jrc/en (accessed on 14 August 2021))) 
standing out, which provides continuity to the work previously developed to define the digital competence of citizens in general (DigComp) [15].

The specific digital competencies for educators are organized into six areas: (a) professional commitment, (b) digital resources, (c) digital pedagogy, evaluation and feedback, (d) empower students and (e) facilitate students' digital competence, with three levels of competence in each one. In this regard, the Autonomous Community of Andalusia [16] establishes in Article 4, for teachers who carry out their work in the Andalusian educational system, both public and private, the Framework for Teaching Digital Competence (DigCompEdu).

Within this competence context for teachers, our study focused on the second area, "digital resources", because although there are many studies that have been carried out on the technological competencies possessed by different people who make up the teachinglearning process $[17,18]$, this aspect has not been studied as much despite the fact that, in the new reality raised by the pandemic, the need to use said educational resources securely, correctly and openly by all educational system agents has been proven.

These educational resources have been well defined and differentiated [19], and some of them were created specifically for university education [20]. However, we must deepen and reflect on the training that is being provided to future education teachers, asking ourselves, as [21] did:

- Do our students (future teachers) know the digital resources and tools?

- Have university professors used these resources to teach the subjects?

- Will our students know how to create appropriate digital resources for their future pupils?

- Will our students know how to collaborate with other teachers and parents on the selection, creation, modification and protection of educational digital resources?

That is, are the students of the Childhood Education Degree of the University of Jaén able to use ICT to obtain, evaluate, store, produce, communicate, present and exchange information and participate in collaboration networks through the internet (Figure 2)?

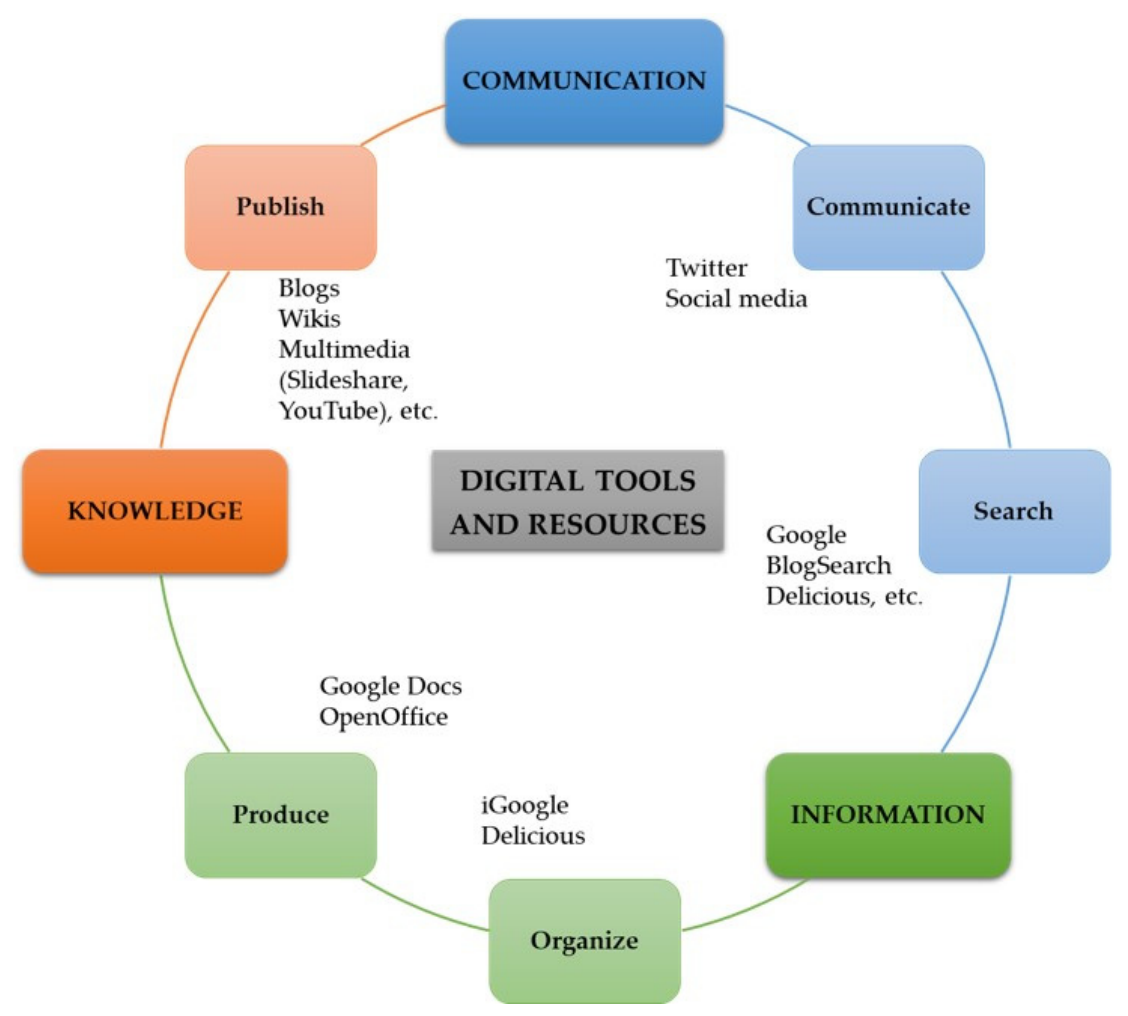

Figure 2. Digital tools and resources. 
Based on the above, the objectives of this study were the following:

1. Identify what the students of the Childhood Education Degree of the University of Jaén use digital resources for.

2. Determine if there are significant differences based on gender in the use of digital resources by the students of the Childhood Education Degree of the University of Jaén.

3. Determine if there are significant differences in the use of digital resources by the students of the Childhood Degree of the University of Jaén depending on the course.

4. Determine if there are significant differences in the use of digital resources by the students of the Childhood Degree of the University of Jaén based on age.

\section{Materials and Methods}

Quantitative and descriptive research was conducted for the development of the research because this type of research allows collecting information from the perceptions of the individuals without making any changes to them since the researchers do not intervene in the reality of the subject studied. As [22] indicated, its main aim is essentially the accurate measurement of one or more dependent variables in a population or a sample of that population.

Percentages, measures of central tendency (mean) and dispersion (standard deviation) were used for the descriptive study. Student's t (difference of means) was used to analyze the differences in relation to the independent variable "gender" and the analysis of variance (ANOVA) in the case of the independent variables "age" and "course".

The purpose of this research was to determine and explain the studied reality in order to draw conclusions and propose contributions to improve it.

\subsection{Procedure}

The questionnaire was distributed and the data were collected among the students of the four courses of the Childhood Education Degree of the University of Jaén in May 2021 using the Google Form tool, and thus it took into account the knowledge obtained by the students during the 2020-2021 academic course.

\subsection{Sample}

The selection of the sample was non-probabilistic and incidental, attending to the following inclusion criteria: (a) students from the University of Jaén; (b) students of the Infant Education Degree; (c) students who were enrolled in the 2020/2021 academic year. For this, all students who met these criteria were asked to respond voluntarily and anonymously to the questionnaire. Data available for the sample are shown in Table 2.

Table 2. Percentage of respondents by course, gender and age.

\begin{tabular}{|c|c|c|c|}
\hline \multicolumn{4}{|c|}{ Course } \\
\hline $1^{\circ}$ & $2^{\circ}$ & $3^{\circ}$ & $4^{\circ}$ \\
\hline $20.3 \%$ & $4.5 \%$ & $26.6 \%$ & $9.5 \%$ \\
\hline \multicolumn{4}{|c|}{ Gender } \\
\hline & & \multicolumn{2}{|c|}{ Female } \\
\hline & & \multicolumn{2}{|c|}{$93.3 \%$} \\
\hline \multicolumn{4}{|c|}{ Age } \\
\hline $18-20$ & $21-23$ & $24-26$ & $\geq 27$ \\
\hline $25.9 \%$ & $50.5 \%$ & $20.7 \%$ & $2.9 \%$ \\
\hline
\end{tabular}

The percentages regarding "participation depending on the course" can be explained since, although the teachers teach in all the courses, at the time of filling out the question- 
naire they were teaching 1st- and 3rd-year subjects, which led to the involvement of the students.

On the other hand, the data related to gender corroborate a particularly striking aspect in this degree, which is the great disparity in the distribution of students by sex. The latest data compiled in the statistical yearbook of the University of Jaén (course 20/21) indicate that there are 21 male students enrolled compared to 196 female students (data: December 2019; source: SIUJA; https:/ / www.ujaen.es/gobierno/anuario/datos-estadisticos / estudiantes / 4212-numero-de-estudiantes-de-nuevo-ingreso-por-centro-titulacion-y (accessed on 14 August 2021)).

\subsection{Instrument}

The measurement instrument was a tool developed to determine the use of the digital resources by the students of the Childhood Education Degree and if they were digitally competent in their use. It was made up of 26 items among which, in this research, we analyzed those grouped in the "use of digital resources" dimension:

- Item 19. The use of digital resources for learning improves your ability to solve problems (for example: digital libraries, institutional resource centers, repositories, portals, online courses, books, articles, digital teaching materials, guides, blogs, forums, social networks, etc.).

- Item 20. The use of digital resources for learning supports the creation of new ideas and content.

- Item 21. The use of digital resources in your learning favors the level of security and confidence during the development of your school activities.

- Item 22. The use of digital resources in your learning stimulates your interest in the studied subject.

- Item 23. The use of digital resources in your learning favors social and communication skills.

- Item 24. The use of digital resources in your learning favors cooperation and collaborative work in the development of common tasks.

- Item 25. The digital resources to which you have access respond to your learning needs and/or interests.

- Item 26. The digital resources offered by ILIAS (Integriertes Lern-, Informationsund Arbeitskooperations System is the German acronym for Integrated Learning, Information and Cooperation System; it is the online platform used by the University of Jaén to facilitate teaching and learning tasks for students and teachers) make learning easier for you.

Each of the items that made up the dependent variable had five response options: $1=$ Never; 2 = Rarely; 3 = Sometimes; 4 = Often; 5 = Always. In addition, the influence of three independent variables - gender, age and course-was studied.

To measure the internal consistency of the developed instrument, Cronbach's alpha coefficient was calculated, obtaining an $\alpha=0.925$ which, according to [23], is a result that allows one to consider the instrument reliable.

In addition, the Kaiser-Meyer-Olkin (KMO) sampling adequacy index, which measures the sampling adequacy for each variable in the model and for the complete model, was calculated. This statistic is a measure of the proportion of variance among variables that might be common variance. The lower the proportion, the more suited the data are to factor analysis. The obtained result $(\mathrm{KMO}=0.741)$ means that the obtained data are valid as indicated by [24].

\section{Results}

Data from the survey were encoded and analyzed using the SPSS software package for Windows, version 27.0.

An analysis of the items through frequencies and percentages, as well as a descriptive analysis (means and standard deviations) of each one of the items of the questionnaire, was 
carried out to determine, as the main objective of the research, various aspects related to the use of technological resources by graduates who were studying for a master's degree. In addition, an analysis of variance (ANOVA) was used to study the specific objectives depending on the sociodemographic variables "age" and "course", while the difference of means (Student's t) was used for the variable "gender". A confidence level of $99 \%$ was used for the ANOVA analyses conducted (significance $p<0.01$ ) and a confidence level of $95 \%$ for the Student's $t$ analyses (significance $p<0.05$ ).

\subsection{Descriptive Statistics}

The following results were obtained regarding the behavior of mode. That is, higher frequencies are located in the "agreements" and the lowest in the "disagreements". This is why this descriptive statistic of centralization shows us the number of individuals of the population who choose each option within each item, which is indicative of its greater or lesser relevance.

Data obtained for the descriptive statistics are shown in Table 3.

Table 3. Descriptive statistics.

\begin{tabular}{|c|c|c|c|c|c|c|c|}
\hline Item & $\% 1$ & $\% 2$ & $\% 3$ & $\% 4$ & $\% 5$ & Mean & $\begin{array}{l}\text { Standard } \\
\text { Deviation }\end{array}$ \\
\hline $\begin{array}{l}\text { 19. The use of digital resources for } \\
\text { learning improves your ability to } \\
\text { solve problems }\end{array}$ & 1.5 & 5.9 & 23.7 & 40.7 & 28.1 & 3.88 & 0.939 \\
\hline $\begin{array}{l}\text { 20. The use of digital resources for } \\
\text { learning supports the creation of } \\
\text { new ideas and content }\end{array}$ & 0 & 8.9 & 16.3 & 42.2 & 32.6 & 3.99 & 0.922 \\
\hline $\begin{array}{l}\text { 21. The use of digital resources in } \\
\text { your learning favors the level of } \\
\text { security and confidence during the } \\
\text { development of your } \\
\text { school activities }\end{array}$ & 0.7 & 5.9 & 19.3 & 45.2 & 28.9 & 3.96 & 0.888 \\
\hline $\begin{array}{l}\text { 22. The use of digital resources in } \\
\text { your learning stimulates your } \\
\text { interest in the studied subject }\end{array}$ & 0 & 8.9 & 25.9 & 33.3 & 31.9 & 3.88 & 0.962 \\
\hline $\begin{array}{l}\text { 23. The use of digital resources in } \\
\text { your learning favors social and } \\
\text { communication skills }\end{array}$ & 3 & 8.9 & 25.9 & 37 & 25.2 & 3.73 & 1.033 \\
\hline $\begin{array}{l}\text { 24. The use of digital resources in } \\
\text { your learning favors cooperation } \\
\text { and collaborative work in the } \\
\text { development of common tasks }\end{array}$ & 3 & 5.9 & 25.9 & 40 & 25.2 & 3.79 & 0.988 \\
\hline $\begin{array}{l}\text { 25. The digital resources to which } \\
\text { you have access respond to your } \\
\text { learning needs and/or interests }\end{array}$ & 0 & 6.7 & 23 & 40.7 & 29.6 & 3.93 & 0.891 \\
\hline $\begin{array}{l}\text { 26. The digital resources offered by } \\
\text { ILIAS make learning easier for you }\end{array}$ & 3.7 & 12.6 & 24.4 & 34.8 & 24.4 & 3.64 & 1.097 \\
\hline
\end{tabular}

1 = Never; 2 = Rarely; 3 = Sometimes; 4 = Often; 5 = Always.

Table 3 shows that the perceptions of the students on the different aspects of the use of the digital resources studied obtained an average that ranges between 3.64 (item 26) and 3.99 (item 20). This indicates that the use of these resources for learning, as well as the attitude of the students toward using them, is widely favorable. Strangely enough, the item with the lowest mean is the one with the highest standard deviation (s.d. = 1.097), which indicates a large dispersion in the response. Item 21 is the one with the lowest 
standard deviation (s.d. $=0.888)$, which indicates that the majority of students $(4+5=74 \%)$ considered that the use of digital resources favored their level of learning.

On the other hand, Figure 3 shows that the items most related to motivation (items 20 and 22) and to easy access to the resources that students need (item 25) have a clear bias toward agreement since answer 1 (Never) has a value of 0 in all of them. Very close to this value, item 21 stands out since only one of the respondents $(0.7 \%)$ thought that the use of digital resources in their learning never favored their level of security and confidence during the development of their school activities.

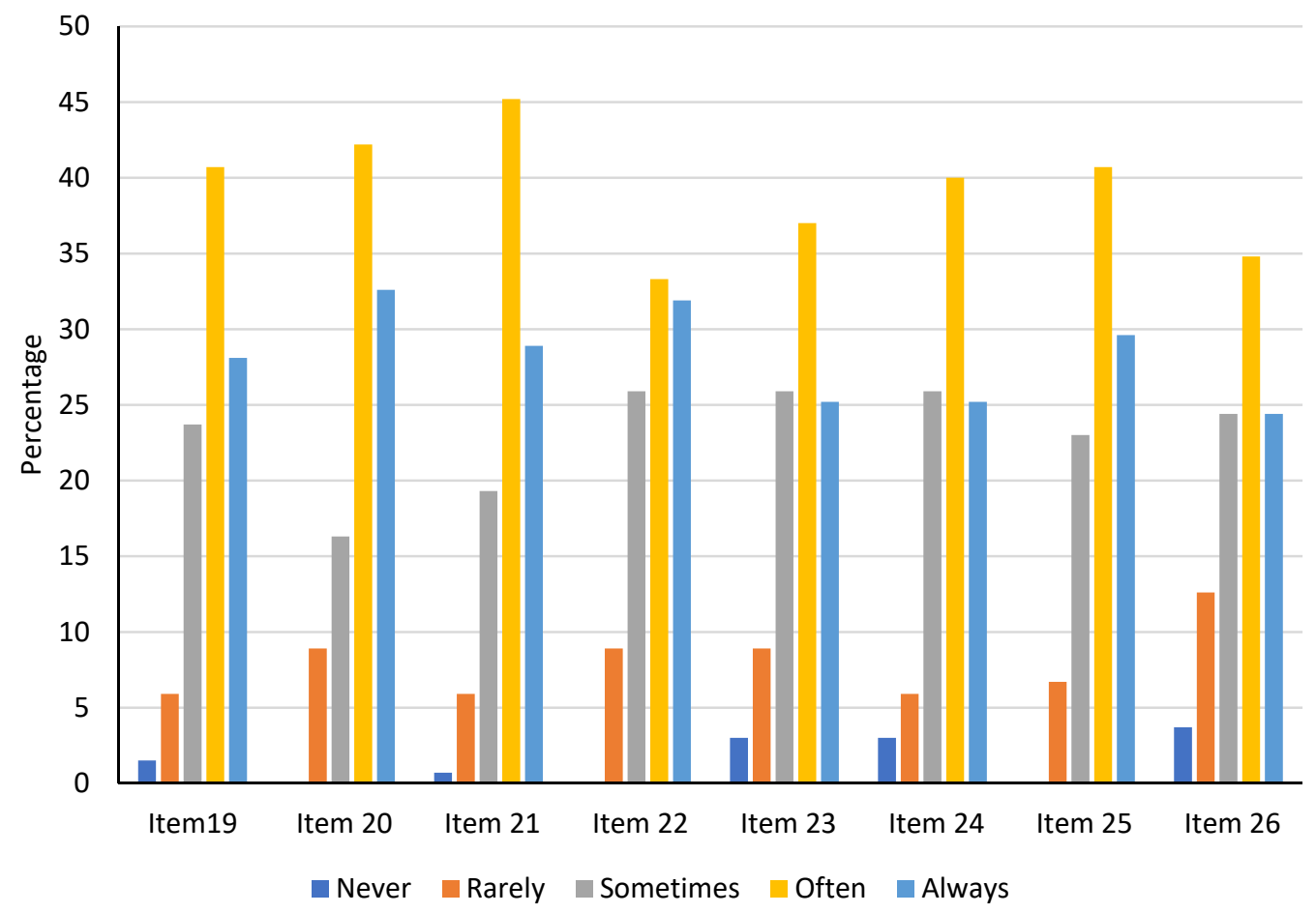

Figure 3. Percentage of responses to the studied items.

\subsection{Analysis of Variance}

No significant differences were found as a function of the variables "age" and "course" (ANOVA, $p<0.01$ ) and "gender" (Student's $t, p<0.05$ ) in any of the items analyzed, with the exception of item 26 for the variable "course" ( $\mathrm{F}=4.161$ and $p=0.007)$.

Table 4 shows the results of the analysis of means depending on the gender and the analysis of variance depending on the age and the course of the students.

Table 4. Significant differences obtained for the independent variables (item 26).

\begin{tabular}{ccccccc}
\hline Item & \multicolumn{2}{c}{ Gender } & & Age & & \multicolumn{2}{c}{ Course } \\
\hline & \multicolumn{2}{c}{ Student's } & & & \multicolumn{2}{c}{ ANOVA } \\
\hline & $\mathbf{t}$ & MD & F & Sig. & F & Sig. \\
\hline $\begin{array}{c}\text { The digital resources offered by ILIAS } \\
\text { make learning easier for you }\end{array}$ & -0.859 & -0.325 & 0.96 & 0.41 & $\mathbf{4 . 1 6}$ & $\mathbf{0 . 0 0 7}$ \\
\hline
\end{tabular}

It shows that people in the final years of the Degree consider that the use of the digital platform of the University of Jaén (ILIAS) does facilitate their learning, in contrast to what is indicated by first- and second-year students. 


\section{Discussion}

The students of the Childhood Education Degree of the University of Jaén have a very favorable attitude toward the use of digital resources. This attitude can be described as very practical and functional for organizing their learning tasks. This result is very similar to other studies conducted where the digital attitude and competence of students were analyzed [25-27].

In accordance with other studies carried out [28-30], the research shows that the use of digital tools during their study stage offers the students a higher level of confidence in achieving their academic objectives, as well as increasing interest in the subject studied.

Moreover, the use of digital resources provides degree students with a series of advantages related to social, communication and collaborative work skills. In the same vein, [31] carried out a study whose results support that designing digital storytelling in a collaborative way promotes socialization among colleagues and mutual help, as well as the development of social skills.

On the other hand, we did not find significant differences in the use of digital resources based on sociodemographic variables. This result is consistent with other investigations, although we could find discordances in the gender variable. For example, the achieved results corroborate those obtained by [32], although other studies indicate the existence of differences regarding the use of digital resources based on gender [33], suggesting it is an influential factor for the integration in the teaching practice and that it is necessary to study to minimize the so-called digital gender gap [34-36].

Finally, there were significant differences in the degree of satisfaction with the resources offered by the virtual learning platform of the University of Jaén (ILIAS) depending on the course in which the students were enrolled; students of the final courses felt more satisfied since they thought it made it easier for them to learn the subjects. It is possible that this response was due to the fact that, as students use digital tools more, they become easier to use, and thus, they achieve better results, which motivates the students to continue using them. In line with this, a study carried out by $[37,38]$ indicated that satisfaction with the use of digital educational resources is mainly related to students' motivation.

\section{Conclusions}

This research shows that the students of the Childhood Education Degree at the University of Jaén (Spain) have a fairly positive attitude toward, motivation for and predisposition to the use of digital resources to facilitate their own learning.

Likewise, regular use of these resources provides the students with a series of benefits closely related to social skills, which are a very important basis for academic success.

No significant differences were found in the use of digital resources based on the sociodemographic variables. However, a significant difference, depending on the course, in relation to whether the digital resources provided by the virtual teaching platform of the University of Jaén (ILIAS) facilitate the learning of the students or not was found. In this case, the highest average was found in the later courses of the Degree (third and fourth year).

Based on the findings of this study, we believe that it would be interesting to explore this line of research extending it to students of different degrees and postgraduates, as well as from different geographical contexts at a national and international level.

Finally, looking ahead, it would be useful to carry out a qualitative study with data triangulation and thus have the opportunity to determine the influence of all these variables on students' future academic and professional success. 
Author Contributions: Conceptualization, M.d.C.M.-S. and E.P.-N.; methodology, M.d.C.M.-S. and M.T.O.-M.; software, M.d.C.M.-S. and M.T.O.-M.; validation, M.T.O.-M. and E.P.-N.; formal analysis, M.T.O.-M. and M.d.C.M.-S.; investigation, M.T.O.-M., M.d.C.M.-S. and E.P.-N.; resources, E.P.-N., M.T.O.-M. and M.d.C.M.-S.; data curation, E.P.-N., M.T.O.-M. and M.d.C.M.-S.; writing-original draft preparation, E.P.-N., M.T.O.-M. and M.d.C.M.-S.; writing-review and editing, M.T.O.-M., E.P.-N. and M.d.C.M.-S.; visualization, E.P.-N., M.T.O.-M. and M.d.C.M.-S.; supervision, M.d.C.M.-S., M.T.O.-M. and E.P.-N.; project administration, E.P.-N., M.T.O.-M. and M.d.C.M.-S.; funding acquisition, M.d.C.M.-S., M.T.O.-M. and E.P.-N. All authors have read and agreed to the published version of the manuscript.

Funding: This research was funded by University of Jaén, grant number PID64_201617 and the Research Project Code EDU2015-70491-R. The APC was funded by University of Jaén and Ministry of Science and Technology.

Acknowledgments: The authors would like to thank the teachers and students for their cooperation in this study.

Conflicts of Interest: The authors declare no conflict of interest. The funders had no role in the design of the study; in the collection, analyses, or interpretation of data; in the writing of the manuscript, or in the decision to publish the results.

\section{References}

1. Bolívar, A. La planificación por competencias en la reforma de Bolonia de la educación superior: Un análisis crítico. ET-Educ. Temática Digit. 2007, 9, 68-94. Available online: https:/ / nbn-resolving.org/urn:nbn:de:0168-ssoar-73427 (accessed on 10 May 2021). [CrossRef]

2. Marentic-Pozarnik, B. From Green to Red Tomatoes or Is there a Shortcut by which to Change the Conceptions of Teaching and Learning of College Teachers? High. Educ. Eur. 1998, 23, 331-338. [CrossRef]

3. Real Decreto 1393/2007, de 29 de Octubre, por el que se Establece la Ordenación de las Enseñanzas Universitarias Oficiales. BOE $\mathrm{N}^{\circ}$ 260, del 30 de octubre de 2007. Available online: https:/ / www.boe.es/buscar/pdf/2007/BOE-A-2007-18770-consolidado.pdf (accessed on 14 May 2021).

4. Pérez Ferra, M. Evaluación y Desarrollo de las Competencias Comunicativa y Digital en Estudiantes del Grado de Maestro; Graó: Barcelona, Spain, 2019.

5. ANECA. Libro Blanco. Título de Grado en Magisterio; Volume 1. 2004. Available online: http://www.aneca.es/var/media/1504 04/libroblanco_jun05_magisterio1.pdf (accessed on 17 May 2021).

6. ANECA. Documentos y publicaciones. Libros Blancos. 2004. Available online: http://www.aneca.es/Documentos-ypublicaciones/Libros-Blancos (accessed on 17 May 2021).

7. European Commission. Safe and Critical Use of Information Society Technologies (IST) for Work, Leisure and Communication. 2006. Available online: https://eur-lex.europa.eu/legal-content/EN/TXT/PDF/?uri=CELEX:32006H0962 (accessed on 21 May 2021).

8. Durán, M.; Gutiérrez, I.; Prendes, M.P. Análisis conceptual de modelos de competencia digital del profesorado universitario. RELATEC Rev. Latinoam. Tecnol. Educ. 2016, 15, 97-114.

9. Carretero, S.; Vuorikari, R.; Punie, Y. DigComp 2.1. The digital Competence Framework for Citizens with Eight Proficiency Levels and Examples of Use. 2017. Available online: http:/ / publications.jrc.ec.europa.eu/repository/bitstream/JRC106281/webdigcomp2.1pdf_(online).pdf (accessed on 15 May 2021).

10. European Commissión Europea. DigCompOrg. Digitally Competent Educational Organisations. 2016. Available online: https:/ / ec.europa.eu/jrc/en/digcomporg (accessed on 21 May 2021).

11. Gisbert, M. Una Tecnología Educativa para la Era Digital. Manuscrito no Publicado, Proyecto de Cátedra; Universidad Rovira i Virgili: Tarragona, Spain, 2017.

12. INTEF; Instituto Nacional de Tecnologías Educativas y de Formación del Profesorado. Marco Común de Competencia Digital Docente. 2017. Available online: https://intef.es/Noticias/marco-comun-de-competencia-digital-docente-2017-intef/ (accessed on 24 May 2021).

13. Gutiérrez, I. Perfil del profesor universitario español en torno a las competencias en tecnologías de la información y la comunicación. Píxel-Bit. Rev. Medios Educ. 2014, 44, 51-65. [CrossRef]

14. Ferrari, A. DIGCOMP: A Framework for Developing and Understanding Digital Competence in Europe; JRC-IPTS: Seville, Spain, 2013. Available online: http:/ /ipts.jrc.ec.europa.eu/publications / pub.cfm?id=6359 (accessed on 12 May 2021).

15. Cabero-Almenara, J.; Palacios-Rodríguez, A. Marco Europeo de Competencia Digital Docente «DigCompEdu» y cuestionario «DigCompEdu Check-In». EDMETIC Rev. Educ. Mediática TIC 2020, 9, 213-234. [CrossRef] 
16. Orden de 29 de Marzo de 2021, por la que se Establecen los Marcos de la Competencia Digital en el Sistema Educativo no Universitario de la Comunidad Autónoma de Andalucía. Boletín Oficial de la Junta de Andalucía, N 67, 150-162. Available online: https:/ / www.juntadeandalucia.es/educacion/portals/delegate/content/50599994-ac98-4feb-870f-a0b04081aa75 (accessed on 21 May 2021).

17. Cabero-Almenara, J.; Barroso-Osuna, J.; Rodríguez-Gallego, M.; Palacios-Rodríguez, A. La Competencia Digital Docente. El caso de las universidades andaluzas. Aula Abierta 2020, 49, 363-372. [CrossRef]

18. Martínez-Serrano, M.C. Percepción de la Integración y uso de las Tecnologías de la Información y la Comunicación (TIC). Estudio de Profesores y Estudiantes de Educación Primaria. Inf. Tecnológica 2019, 30, 237-246. [CrossRef]

19. Colomé, D. Objetos de aprendizaje y recursos educativos abiertos en Educación Superior. EDUTEC-Rev. Electrónica Tecnol. Educ. 2019, 69, 89-101. [CrossRef]

20. Manrique-Losada, B.; Zapata Cárdenas, M.I.; Arango Vásquez, S.I. Entorno virtual para cocrear recursos educativos digitales en la educación superior. Campus Virtuales 2020, 9, 101-112.

21. Pérez-Ortega, I. Creación de Recursos Educativos Digitales: Reflexiones sobre Innovación Educativa con TIC. Int. J. Sociol. Educ. 2017, 6, 244-268. [CrossRef]

22. Hyman, H.H. Survey Design and Analysis Principles, Cases, and Procedures; The Free Press: Ontario, ON, Canada, 1955.

23. Morales, P. Estadística Aplicada a las Ciencias Sociales: La Fiabilidad de los Tests y Escalas; Universidad Pontificia de Comillas: 2007. Available online: http:/ / www.upcomillas.es/personal/peter/estadisticabasica/Fiabilidad.pdf (accessed on 28 May 2021).

24. Ocaña, M.T.; Pérez, M.; Quijano, R. Elaboración y validación de una escala de creencias de los alumnos de Educación Secundaria Obligatoria respecto al medio ambiente. Profesorado 2013, 17, 432-454. Available online: https://www.ugr.es/ \{\}recfpro/rev171 COL10.pdf (accessed on 28 May 2021).

25. Cervantes, M.L.P.; Barros, A.F.S. Importancia del uso de las plataformas virtuales en la formación superior para favorecer el cambio de actitud hacia las TIC: Estudio de caso: Universidad del Magdalena, Colombia. Rev. Iberoam. Evaluación Educ. 2013, 6, 153-166.

26. Padilla Carmona, M.T.; Suárez Ortega, M.; Sánchez García, M.F. Inclusión digital de los estudiantes adultos que acceden a la universidad: Análisis de sus actitudes y competencias digitales. Rev. Complut. Educ. 2016, 27, 1229-1246. [CrossRef]

27. Pérez-Navío, E.; Medina-Domínguez, M.C.; Cachón-Zagalaz, J. Perception of the professional competences of last year's students of Pre-Primary Education and Primary Education degrees and students of training Teachers Master. NAER J. New Approaches Educ. Res. 2019, 8, 58-65. [CrossRef]

28. Peinado Camacho, J.D.J. Experiencias del profesorado acerca del aprendizaje autónomo en estudiantes de modalidad a distancia y el uso de recursos digitales. RIDE Rev. Iberoam. Investig. Desarro. Educ. 2020, 10. [CrossRef]

29. Valencia, A.J.A.; Moreno, P.D.C. El uso de las TIC como herramienta de motivación para alumnos de enseñanza secundaria obligatoria. Estudio de caso español. Hamut'ay 2019, 6, 37-49. [CrossRef]

30. Garrido, M.C.D.; Ruiz-Cabezas, A.; Domínguez, M.C.M.; Dueñas, M.C.L.; Pérez Navío, E.; Rivilla, A.M. La formación de docentes en el diálogo y el entendimiento intercultural: Con foco en la educación para un desarrollo sostenible. Sustainability 2020, 12, 9934. [CrossRef]

31. Del Moral Pérez, M.E.; Martínez, L.V.; Piñeiro, M.D.R.N. Habilidades sociales y creativas promovidas con el diseño colaborativo de digital storytelling en el aula. Digit. Educ. Rev. 2016, 30, 30-52.

32. Guillén-Gámez, F.D.; Mayorga-Fernández, M.J.; Contreras-Rosado, J.A. Incidence of Gender in the Digital Competence of Higher Education Teachers in Research Work: Analysis with Descriptive and Comparative Methods. Educ. Sci. 2021, 11, 98. [CrossRef]

33. Gómez Carrasco, C.J.; Chaparro Sainz, Á.; Felices de la Fuente, M.D.M.; Cózar Gutiérrez, R. Estrategias metodológicas y uso de recursos digitales para la enseñanza de la historia: Análisis de recuerdos y opiniones del profesorado en formación inicial. Aula Abierta 2020, 49, 65-74. [CrossRef]

34. Masanet, M.J.; Pires, F.; Gómez-Puertas, L. Riesgos de la brecha digital de género entre los y las adolescentes. Prof. Inf. 2021, 30, e300112. [CrossRef]

35. Martínez-Cantos, J.L.; Castaño, C. La brecha digital de género y la escasez de mujeres en las profesiones TIC. Panor. Soc. 2017, 25, 49-65.

36. Velázquez, S.C.A.; Amador, E.M.P. La brecha digital de género como factor limitante del desarrollo femenino. Boletín Científico Investigium Esc. Super. Tizayuca 2020, 5, 22-27. [CrossRef]

37. Alberola-Mulet, I.; Iglesias-Martínez, M.J.; Lozano-Cabezas, I. Teachers' Beliefs about the Role of Digital Educational Resources in Educational Practice: A Qualitative Study. Educ. Sci. 2021, 11, 239. [CrossRef]

38. Cabea, A.R.C.; Domínguez, M.d.C.M.; Navio, E.P.; Rivilla, A.M. University teachers' training: The Digital Competence. [Formación del profesorado Universitario en la Competencia Digital]. Pixel-Bit. Rev. Medios Educ. 2020, 58, 181-215. [CrossRef] 